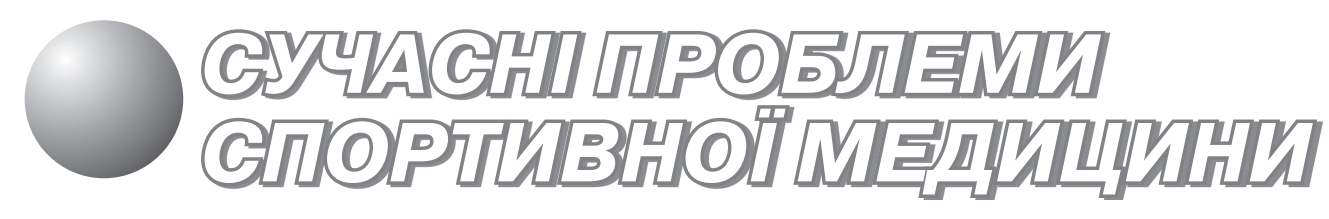

DOI: https://doi.org/10.32652/spmed.2020.1.3-9

\section{Громадське здоров'я: дискусійні питання, шляхи їх практичного вирішення}

\author{
УДК 796.034.-05
}

\author{
М. В. Дутчак, Л. Я.-Г. Шахліна, С. М. Футорний, \\ Я. В. Першегуба
}

Національний університет фізичного виховання і спорту України, Київ, Україна

Резюме. Ціль. Охарактеризувати поняття «громадське здоров'я», фактори, що його визначають, для формування стратегії і тактики розвитку охорони здоров'я. Методи. Аналіз наукової, науково-методичної літератури. Результати. В історичному аспекті представлено поняття «здоров'я», дискусійні подання цього стану. Відповідно до думки проф. М. П. Захарченка [9], «...здоров'я людини ... завжди залежало, залежить і буде залежати від середовища ї̈ перебування, тобто від факторів навколишнього середовища, і порушувати питання про здоров'я як про автономне явище - це утопія» [9]. Представлено характеристику здорового організму, здорового способу життя, в якому поєднуються гармонійно фізичне, психічне й соціальне здоров'я. Наведено фізіологічні механізми позитивних ефектів рухової активності для людини. Розглянуто поняття «громадське здоров'я», його багатофакторність. Встановлено, що в Україні з 2011 р. у вищих медичних навчальних закладах IV рівня акредитації назву навчальної дисципліни «соціальна медицина й організація охорони здоров'я» було змінено на «громадське здоров'я» відповідно до її змісту в більшості країн світу. Висновок. У 2018 р. спеціальність Громадське здоров'я було ліцензовано в Україні, що спричинило необхідність проведення медичної реформи і підготовки нових кадрів за європейськими стандартами. Підготовка фахівців у цьому напрямі проводиться за фахом 229 Громадське здоров'я (галузь знань - 22 Охорона здоров'я) на трьох рівнях освіти: бакалавр, магістр і доктор філософії [5].

На базі НУФВСУ на підставі ліцензії з підготовки фахівців вищої освіти на першому (бакалаврському) рівні вищої освіти (наказ МОН України від 12.12.19 № 1010п) проводиться підготовка до навчання за ліцензованою спеціальністю 229 Громадське здоров'я.

Ключові слова: здоров'я, громадське здоров'я, заклади вищої освіти, дискусійні питання.

Public health: debatable issues, ways of their practical solution

M. V. Dutchak, L. I.-H. Shakhlina, S. M. Futornyi, I. V. Pershehuba

National University of Physical Education and Sport of Ukraine, Kyiv, Ukraine

Abstract. Objective. To characterize the concept of "public health", its determining factors for the formation of strategies and tactics of healthcare development. Methods. Analysis of scientific, scientific and methodological literature. Results. The concepts of "health", debatable representations of this condition are presented. According to prof. M. P. Zakharchenko [9], "... human health ... has always depended, depends and will depend on its environment, that is, environmental factors; therefore, raising the question of health as an autonomous phenomenon is utopia" [9]. The characteristic of a healthy body, a healthy lifestyle combining harmoniously physical, mental and social health, is presented. The article presents the physiological mechanisms of motor activity positive effects for humans. The concepts of public health, its multifactorial nature are considered. It has been established that in 2011 in higher medical schools of Ukraine of the IV level of accreditation, the name of the discipline "Social Medicine and Health Protection Organization" was changed to "Public Health" in accordance with its content in most countries of the world. Conclusion. In 2018, the Public Health 
specialty was licensed in Ukraine, which necessitated a medical reform and preparation of new personnel according to European standards. Preparation of specialists in this field is carried out in the specialty 229 Public Health (field of expertize - 22 Health) at three levels of education: bachelor, master and doctor of philosophy [5].

On the basis of the NUPESU, preparation is being made for training in the licensed specialty 229 Public Health in accordance with a license to prepare higher education specialists at the first (bachelor's) level of higher education (order of the Ministry of Education and Science of Ukraine dated 12.12.19 N $1010 \mathrm{p}$ ).

Keywords: health, public health, higher education institutions, argumentative issues.

Постановка проблеми. Існує велика кількість визначень поняття «здоров'я», однак жодне $з$ них не $\epsilon$ абсолютним. На думку Е. Г. Булич, І. В. Муравова [3], це пов'язано головним чином з тим, що в здоров'я немає конкретних і стабільних проявів. «Якщо в організмі все благополучно і немає жодних змін, то органи його “мовчать"». Наші багаторічні дослідження дали можливість дійти висновку, що здоров'я - на відміну від хвороби - не має симптомів [4].

В Уставі ВОЗ (1948) записано «Здоров'я - це стан повного фрізичного, духовного і соціального благополуччя, а не лише відсутність хвороби або фрізичних дефектів». На думку М. М. Ібрагімова [10], сфрормульоване більш ніж піввікове визначення здоров'я ВОЗ «...виявилося настільки вдалим, що витримало удари різноманітних світоглядних парадигм» [10].

На думку авторів статті, важко уявити можливість стану повного фрізичного, духовного й соціального благополуччя сучасного суспільства, тому ми не погоджуємось із думкою М. М. Ібрагімова і представниками науки, які продовжують підтримувати визначення ВОЗ.

Критичне ставлення до визначення здоров'я ВОЗ (1948) висловили J. Passmore і співавт. [27], вважаючи, що воно характеризується занадто загально, не містить жодних відомостей щодо практичної діяльності [27].

«Тверда критика дефрініції здоров'я, прийнята ВОЗ, цілком на це заслуговує. Дійсно, визначення і занадто розпливчасте, і не може слугувати практичним цілям, й ідеалістичне - чи часто ми зустрічаємо "повне фрізичне, духовне і соціальне благополуччя?" "» [4].

Точнішим з наукового погляду варто вважати таке визначення: «Здоров'я - це відносно досконала й стійка форма життєдіяльності, здатна забезпечити економічні оптимальні механізми адаптації до довкілля, сформувати функціональні резерви, що використовуються при ії̈ змінах» [8].

На думку Е. Г. Булич та І. В. Муравова, «...здоров'я завжди було і назавжди залишиться найважливішим пріоритетом, тим станом, до якого прагне кожний, розуміючи, що ніщо - ні багат- ство, ні суспільне становище не в змозі замінити здоров'я» [3].

Як зазначає профресор М. П. Захарченко [9], «здоров'я людини ... завжди залежало, залежить і буде залежати від середовища іiї перебування, тобто від фракторів навколишнього середовища, і порушувати питання про здоров'я як про автономне явище - це утопія».

Діапазон адаптації кожної людини формується на генетичній основі, однак така можливість може бути значно розширеною внаслідок систематичної рухової активності, загартування, здорового способу життя [28].

Здоровий організм характеризується здатністю:

- ефрективно використовувати свої морфофункціональні можливості при пред'явленні йому підвищених вимог;

- швидко й адекватно реагувати, пристосовуючись до нових умов без патологічних ознак при цьому;

- швидко функціонально відновлюватися до вихідного стану з підвищенням працездатності, збереженням гарного самопочуття [23].

Створення наукового обгрунтування оздоровлення суспільства засобами фрізичної культури і спорту пропагували ще в середині минулого століття академік М. М. Амосов [1], доктор Кеннет Купер [13] особистим прикладом занять фрізичною культурою. Професор І. В. Муравов запропонував створити спеціалізований дослідницький інститут для розробки проблем фрізкультури, спорту і здоров'я. За підтримки Уряду України у 1969 р. у Києві було створено Науково-дослідний інститут медичних проблем фрізичної культури із клінікою здорової людини. Його очолив профресор І. В. Муравов. Діяльність інституту була спрямована на планомірні дослідження здоров'я спортсменів і осіб, які займаються оздоровчою фрізкультурою [21]. На жаль, у 1986 р. інститут було реструктуризовано і на його базі після трагедії на Чорнобильській атомній електростанції організовано Український науково-дослідний центр радіаційної медицини.

Збереження здоров'я повною мірою залежить від рівня культури життя, відображаючи 
усвідомлення і ставлення людини до себе, її знання про здоров'я, рухову активність.

Гармонійне поєднання фрізичного, психічного й соціального здоров'я $€$ важливим чинником формування здорового способу життя (ЗСЖ), забезпечуючи профрілактику виникнення різних захворювань у людини [6].

Рухова активність людини - це сумарний обсяг рухів, які вона виконує протягом життя.

Водночас гіподинамія - один із негативних фракторів, що впливає на здоров'я людини.

Сучасна людина знає про здоров'я досить багато, знає й про те, що потрібно робити для його досягнення і підтримання [24]. На думку авторів:

- у країні має існувати послідовна і безперервна система навчання зі збереження здоров'я;

- необхідно створювати в людини обгрунтовано стійку мотивацію для підтримки ЗСЖ основи здоров'я.

На думку видатного фрахівця в галузі спортивної медицини А. Г. Дембо, «...заняття фрізичною культурою і спортом оздоровлюють лише тоді, коли навантаження відповідають індивідуальним функціональним можливостям людського організму, дотримуються режими праці й відпочинку, харчування» [7].

Аналізуючи фрізіологічні механізми позитивних ефректів рухової активності, варто зазначити, що за фрізичних навантажень умовно «головною фрункціональною системою» організму є система опорно-рухового апарату, всі інші функціональні системи організму $є$ «обслуговуючими» (системи дихання, кровообігу, крові, виділення та ін.) [2].

У процесі рухової активності збудження від пропріорецепторів м'язів, суглобів, зв'язок передається через центральну нервову систему (ЦНС) до всіх внутрішніх органів і тканин, фооруючи і вдосконалюючи моторно-вісцеральні рефлекси [18], втягуючи в рухову діяльність, відповідно навантаженню, роботу серця, легенів, систему травлення, терморегуляції й, передусім, ЦНС. Центральна нервова система разом із залозами внутрішньої секреції забезпечує механізми біологічної регуляції, спрямовані на координацію й інтеграцію фрункцій усіх систем організму для оптимальної адаптації його до конкретних фрізичних навантажень. Таким чином, рухова активність людини забезпечує збільшення функціональних можливостей не лише опорно-рухового апарату, а й систем дихання, кровообігу, крові й, звичайно, ЦНС.

Адаптаційні можливості організму до пропонованих фрізичних навантажень (при дотриманні принципу поступовості збільшення фрізичних навантажень, систематичності їх виконання) проявляються в економічності функцій систем
Спортивна медицина і фізична реабілітація, № 1, 2020

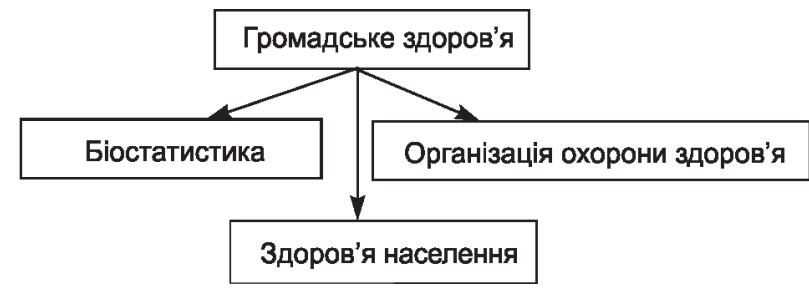

Рисунок 1 - Структура предмета «громадське здоров'я» [5]

організму - зменшенні в стані спокою частоти серцевих скорочень (ЧСС), частоти дихання (ЧД), скороченні часу відновлення після фрізичних навантажень. Оздоровчий ефект рухової активності проявляється, таким чином, у підвищенні фрункціональних можливостей організму, його працездатності, у поліпшенні якості життя людини [23].

Мета дослідження - охарактеризувати поняття «громадське здоров'я», фрактори, що його визначають, для фрормування стратегії і тактики розвитку охорони здоров'я.

Методи і організація дослідження: теоретичний аналіз і узагальнення даних науково-методичної літератури й даних мережі Internet.

Результати дослідження та їх обговорення. Здоров'я можна розглядати не лише в аспекті особистості, а й як:

- здоров'я суспільства в цілому;

- здоров'я середовища, тобто всі аспекти перебування людини в ньому, в тому числі й дії, спрямовані на поліпшення якості цього середовища для збереження здоров'я популяції [25].

Існує поняття «громадське здоров'я», що на відміну від клінічних дисциплін вивчає здоров'я не окремих індивідів, а соціальних груп і суспільства в цілому, установлюючи при цьому зв'язок здоров'я з умовами життя населення, створюючи основу для фрормування стратегії й тактики розвитку охорони здоров'я [5].

Вивченням здоров'я населення й системи його охорони займається наука «громадське здоров'я». 3 огляду на багатофракторність здоров'я населення за своєю природою, наука «громадське здоров'я» вивчає вплив соціальних, економічних, екологічних, поведінкових, організаційних фракторів на фрормування здоров'я популяції з метою розробки проорілактичних заходів для його поліпшення, а також для оптимізації медичного обслуговування.

В Україні з 2011 р. у вищих медичних навчальних закладах IV рівня акредитації назву навчальної дисципліни «соціальна медицина й організація охорони здоров'я» було змінено на «громадське здоров'я» відповідно до її змісту в більшості країн світу. 


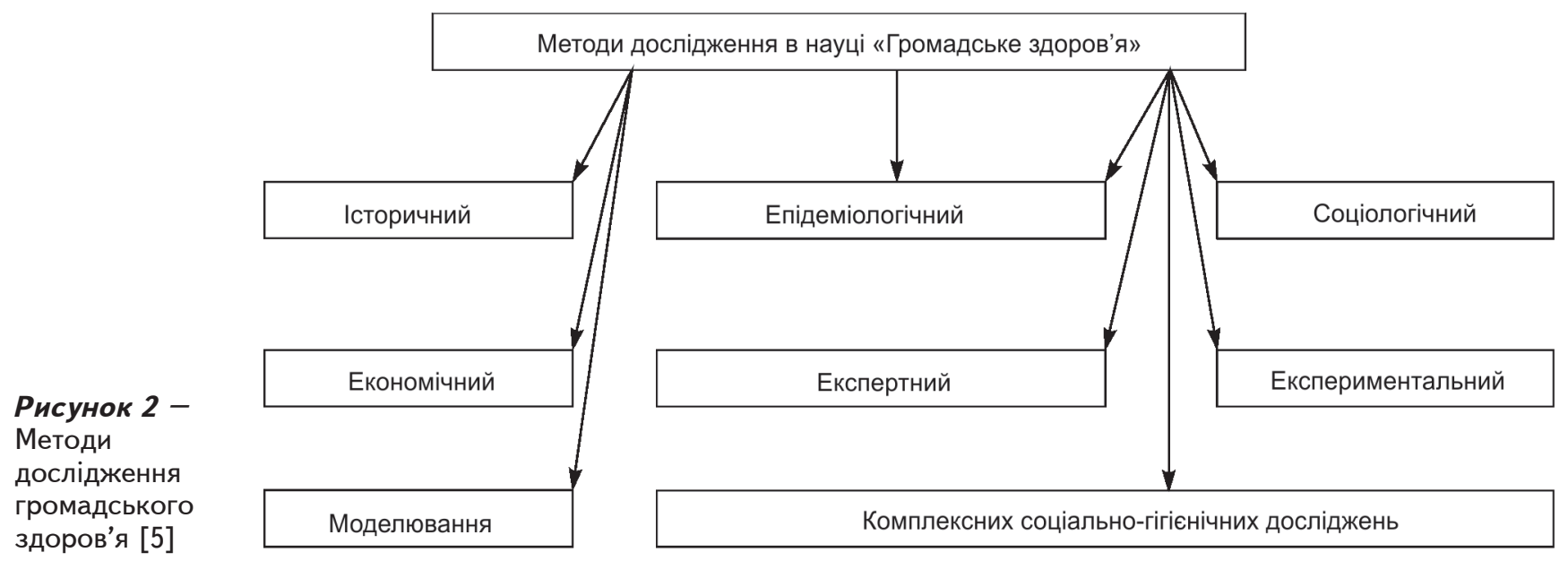

Навчальна дисципліна «громадське здоров'я» включає фондаментальні поняття «здоров'я» $\mathrm{i}$ «охорона здоров'я», особливості їхнього формування, сучасні тенденції трансформації й впливу на розвиток суспільства.

Нове визначення здоров'я розглядається як складова комплексної системи «здоров'я-благополуччя-соціальне благополуччя».

У XXI ст. проблема охорони здоров'я $\epsilon$ пріоритетною й включається до програми авторитетних міжнародних фоорумів, у тому числі й у Саміт тисячоліття $\mathrm{OOH}[5]$.

Основна відповідальність за стан здоров'я населення покладається на національні системи охорони здоров'я.

Метою вивчення громадського здоров'я $€$ надання фахівцям-медикам належного обсягу знань на підставі вітчизняного й закордонного досвіду, нових досягнень науки для підвищення рівня підготовки фрахівців в галузі охорони здоров'я [16].

У різних країнах назва навчальної дисципліни має свої особливості, що залежать від сприйняття й ідентифікації проблем, історії й національних традицій. В англомовних країнах цю навчальну дисципліну називають «громадське здоров'я», «громадська охорона здоров'я», «превентивна медицина» [19].

Вивчення громадського здоров'я, таким чином, спрямоване на стан здоров'я населення у взаємозв'язку із факторами життя, з якістю і доступністю медичної допомоги, на розробку рекомендацій 3 метою виключення впливу шкідливих фракторів і вдосконалення медичного обслуговування [20].

Основні завдання навчальної дисципліни «Громадське здоров'я» спрямовані на:

- вивчення впливу медико-соціальних факторів, умов і якості життя на здоров'я різних груп населення;
- розробку наукових рекомендацій із попередження і ліквідації несприятливих соціальних фракторів і умов, розробку оздоровчих заходів для підвищення рівня здоров'я населення;

- оцінку критеріїв громадського здоров'я i якості медичної допомоги [20].

Автори зазначають, що здоров'я населення як багатоаспектне поняття оцінюється на підставі медичних показників - демографрічних, фрізичного розвитку, захворюваності, інвалідності.

Організацію охорони здоров'я автори розглядають як діяльність, спрямовану на збереження, поліпшення й зміцнення здоров'я різних груп населення. Охорона здоров'я ними розглядається як взаємодія профрілактичних і лікувальних засобів, доступність і якість кваліфрікованої медичної допомоги.

Методологічною основою науки «Громадське здоров'я» $€$ комплекс методів, наведених на рисунку 2.

У 1998 р. ВОЗ прийняла програму «Здоров'я для всіх у XXI столітті», а в 2005 р. було оновлено стратегію досягнення здоров'я для всіх, у якій виключено загальні для всіх країн завдання й акцентовано необхідність фоормування концепції «Здоров'я для всіх», що відповідає національним принципам і цінностям [5].

Система охорони здоров'я України грунтується на досвіді й рекомендаціях міжнародних організацій. Нормативно-правова база охорони здоров'я України включає положення Конституції України, Основ законодавства України з питань охорони здоров'я, закони України [12].

У 2011 р. було внесено зміни й доповнення Основ законодавства України про охорону здоров'я з метою вдосконалення правової основи цієї галузі, підвищення ефективності надання медичної допомоги населенню для забезпечен- 
ня конституційного права громадян на охорону здоров'я, медичну допомогу [19].

Як зазначають фрахівці в галузі громадського здоров'я [20], державна політика з охорони здоров'я України ґрунтується на сучасних досягненнях науки «Громадське здоров'я», світовому міжнародному досвіді, спрямованих на збереження, зміцнення й відновлення здоров'я - важливих складових високої якості життя.

Під час вивчення громадського здоров'я варто враховувати, що фрактори, які впливають на здоров'я населення за їх тісної взаємодії, змінюються в часі, мають регіональні особливості.

Ще в 1980 р. A. I. Robbins [5] згрупував фрактори ризику і їхній вплив на рівень здоров'я населення, серед яких спосіб життя (відсутність або наявність здорового способу життя) обумовлює здоров'я на $50 \%$, генетичні фактори - на $20 \%$, екологічні фрактори - на $20 \%$, стан медичної допомоги - на $10 \%$ (рис. 3).

На сьогодні для оцінки громадського здоров'я використовують групи показників (індикаторів), які досить повно відображають стан громадського здоров'я:

- медико-демографрічні процеси;

- захворюваність;

- інвалідність;

- фрізичне здоров'я [19].

Єдиного критерію, за яким можна визначити стан здоров'я населення, не існує. У світовій практиці використовують комплексний підхід у характеристиці поняття «здоров'я населення» - це умовне статистичне поняття, що характеризується досить повним комплексом медичних показників.

Серед медичних показників здоров'я населення важливу роль відіграє демографрічна характеристика [20].

Статистичне визначення чисельності населення проводиться за такими двома основними напрямами, як статика та динаміка населення.

Рух населення може здійснюватися в результаті механічного руху - в разі переселення (міграції) населення, або природного - співвідношення народжуваності та смертності [5,17].

Демографрія (demos (грець.) - народ, grapho писати) - це наука про статистичну характеристику населення.

Демографрічні дані, характеризуючи стан здоров'я населення, дають змогу науково обгрунтовувати організацію медичної допомоги, вибирати пріоритетні напрямки в галузі охорони здоров'я.

\section{Медико-соціальні аспекти демографії}

Медична демографрія вивчає взаємозв'язок відтворення населення з медико-соціальними фракто-
Спортивна медицина і фізична реабілітація, № 1, 2020

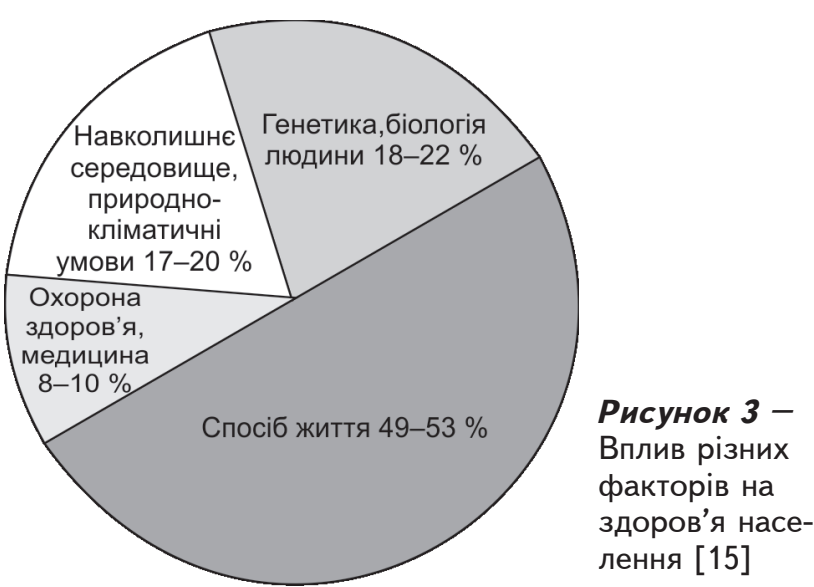

рами й розробляє на цій основі оптимальні заходи сприятливого розвитку демографрічних процесів і поліпшення здоров'я населення. Статистичне вивчення народонаселення проводять у двох таких напрямах - динаміка і статика населення [16].

Динаміка населення вивчає процеси зміни чисельності й структури населення, статика - чисельність і структуру населення на певний період.

Зміна чисельності й структури населення може відбуватися внаслідок механічного руху, зумовленого переселенням - міграцією (зовнішня міграція - перетинання населенням державних кордонів; внутрішня міграція - переміщення населення у межах однієї країни) населення, і внаслідок природного руху, зумовленого народжуваністю і смертністю [16].

Природний рух населення характеризується сукупністю процесів народжуваності, смертності та природного приросту, що забезпечує поновлення і зміну населення [16]. Автори зазначають, що народжуваність у суспільстві детермінована не лише біологічними, а й соціально-економічними умовами життя, етнічними традиціями, релігійними установками.

Статику населення вивчають за такими основними ознаками, як стать, вік, соціальні і професійні групи, шлюб, національність, освіта, громадянство, місце проживання. Ці дані отримують за перепису населення.

Захворюваність - найважливіша складова комплексної оцінки здоров'я населення. Ії̈ медико-соціальне значення полягає в тому, що захворювання $€$ основною причиною смерті, тимчасової або постійної втрати працездатності, зумовлюючи економічніші втрати суспільства, негативний вплив на здоров'я майбутніх поколінь, скорочення чисельності населення $[5,14]$.

\section{Фізичний розвиток}

Фізичне здоров'я $є$ важливим показником рівня здоров'я окремої людини й населення в цілому. 
«Фізичне здоров'я - це інтегральний показник життєдіяльності індивідуума, що характеризується оптимальним рівнем адаптаційних можливостей організму, за яких забезпечується збереження основних параметрів його гомеостазу в умовах впливу факторів навколишнього середовища» [25].

«Фізичне здоров'я людини характеризується низкою інтегративних показників: рівнем і гармонійністю фрізичного і психічного розвитку, фрізичною і розумовою працездатністю, неспецифрічною резистентністю, резервами адаптації, морально-вольовими і ціннісно-мотиваційними установками» [25].

Фізичне здоров'я населення характеризує соціальне благополуччя в суспільстві, передусім дітей.

Таким чином, здоров'я населення зумовлене комплексним впливом фракторів, що визначають спосіб життя людини і стан середовища його перебування - атмоссрерного повітря, води, грунту, рівня добробуту суспільства. Одні фактори позитивно впливають на стан здоров'я, інші потенційно небезпечні й сприяють виникненню хронічних захворювань. Їх відносять до фракторів ризику. Наприклад, серед дорослого населення найпоширенішими фракторами ризику, що піддаються корекції, $\epsilon$ :

- низька рухова активність;

- незбалансоване харчування;

- шкідливі звички;

- психологічна дезадаптація (підвищене психоемоційне навантаження, втома на роботі, соціальна незахищеність).

Усунення або пом'якшення негативного впливу фракторів ризику на здоров'я населення лежить в основі первинної профрілактики і формування здорового способу життя [19].

Розпорядженням Кабінету Міністрів України від 30 листопада 2016 р. № 1002-р схвалена Концепція розвитку системи суспільного здоров'я в Україні [22]. Прийняття документа запроваджує процес стратегічного планування розвитку системи із залученням зацікавлених сторін, планування заходів на національному, регіональному і місцевому рівнях. Прийняття Концепції наблизить практичну реалізацію завдань зі збереження здоров'я і повноцінного життя людей як однієї з найважливіших цілей світової спільноти, відзначених у засобах європейської політики «Здоров'я - 2020».

Реалізація Концепції сприяє створенню ефективної системи розвитку кадрового забезпечення у сорері громадського здоров'я, а саме:

- ресрормування систем переддипломної i післядипломної підготовки працівників системи
«Громадське здоров'я», їх безперервного професійного розвитку, впровадження спеціальності й спеціалізації «Громадське здоров'я»;

- навчання за окремими магістерськими програмами у закладах вищої освіти, на курсах підвищення кваліфрікації або дистанційно для фрахівців, які працюють у сфері громадського здоров'я.

Впровадження дисципліни «Громадське здоров'я» у вищих навчальних закладах за кордоном почалося ще у 2000-ні роки, після прийняття відповідних документів у галузі охорони здоров'я населення їхніх країн. В основі цього науково-практичного напряму лежить профрілактика захворювань, подовження життя і зміцнення здоров'я зусиллями самого суспільства [26].

Закордонні фрахівці вважають, що основний прогрес у галузі охорони здоров'я на майбутні десятиліття ґрунтуватиметься не на нових успіхах медицини, а на розвитку нових програм профрілактики захворювань серед населення внаслідок збільшення фахівців у галузі охорони здоров'я, їхньої кваліфікації з метою підвищення мотивації людини до здорового способу життя.

\section{Висновок}

Фахівці в галузі громадського здоров'я забезпечують населення інформацією щодо впливу екологічних фракторів, гіподинамії на здоров'я людини, принципів здорового способу життя для представників різного контингенту населення країни.

Оскільки фахівцями в галузі «Громадське здоров'я» можуть бути не лише медики, то й підготовка фрахівців у цій галузі має бути відповідною. Так, у закладах вищої освіти за кордоном підготовку за фрахом «Громадське здоров'я» проводять для бакалаврів і магістрів: «Громадське здоров'я», «Охорона здоров'я», «Епідеміологія і біостатистика», «Промоція здоров'я» [11].

В Україні спеціальність Громадське здоров'я було ліцензовано в 2018 р. у зв'язку з необхідністю проведення медичної реформи і підготовки нових кадрів за європейськими стандартами в галузі керування і охорони громадського здоров'я [5].

Підготовка фрахівців в Україні в цьому напрямку проводиться за фахом 229 Громадське здоров'я (галузь знань - 22 Охорона здоров'я) на трьох рівнях освіти: бакалавр, магістр і доктор фрілософрії. Спеціалізації за цією спеціальністю: «Промоція здоров'я», «Менеджмент здоров'я», «Епідеміологія і біостатистика» у закладах вищої освіти, які безпосередньо підпорядковуються і не підпорядковуються Міністерству охорони здоров'я України.

На базі Національного університету з фрізичного виховання і спорту України на підставі ліцензії 
3 підготовки фрахівців вищої освіти на першому (бакалаврському) рівні вищої освіти (наказ МОН України від 12.12.19 № 1010п) проводиться підготовка до навчання за ліцензованою спеціальністю 229 «Громадське здоров'я» перспективних молодих фрахівців на стику галузей науки - охорони здоров'я, менеджменту, економіки, фрізичної культури та спорту для охорони здоров'я кожної людини і населення України в цілому. Майбутні фрахівці НУФВС в галузі «Громадське здоров'я»

\section{Література}

1. Амосов НМ. Раздумья о здоровье [Thinkings about health]. Москва: Молодая гвардия; 1979. 191 с.

2. Анохин ПК. Очерки по фризиологии функциональных систем [Essays on functional systems physiology]. Москва: Медицина; 1975. 447 с.

3. Булич ЭГ, Муравов ИВ. Здоровье спортсменов: научные факты и опасные представления [Health of athletes: scientific facts and dangerous ideas]. Спортивная медицина. 2012; 2: 14-25.

4. Булич ЭГ, Муравов ИВ. Здоровье человека. Биологическая основа жизнедеятельности и двигательная активность в ее стимулячии [Human health. Biological basis of life-sustaining activity and motor activity in its stimulation]. Киев: Олимп. лит.; 2003. 424 c.

5. Громадське здоров'я. За редакцією акад. НАМН України В.Ф. Москаленка / ОП. Гульчій, ТС. Грузєва та ін. Вінниця: Нова книга; 2013; Вип. 3. 560 c.

6. Громадське здоров'я: підручник для студентів вищих навч. закладів / ВФ. Москаленко, ОП. Гульчій, ТС. Грузєва [та ін.]. Вінниця: Нова книга; 2013; Вип. 3; С. 5-17.

7. Дембо АГ. Актуальные проблемы современной спортивной медицины [Actual issues of modern sports medicine]. Москва: Советский спорт; 1980. 295 c.

8. Зайчик АШ. Общая патофизиология с основами иммунологии [General pathophysiology with the basics of immunology]: [учебник]. 4-е изд. I А.Ш. Зайчик, Л.П. Чурилов. СПб.: ЭЛБИ-СПб; 2008. Т. 1: С. 175-196.

9. Захарченко МП. Профилактическое направление в медицине и "новые" науки о здоровье людей [Preventive direction in medicine and "new" sciences about human health]. Гигиена и санитария. 1998; 5:62-4.

10. Ибрагимов ММ. Философия спорта как новый антропологический проект: монография / Киев: НУФВСУ, Олимп. литература; 2014. C. 67-92.

11. Імас $Є B$, Футорний СМ, Уряднікова IB, Маслова ОВ. Спеціальність "Громадське здоров'я" у закладах вищої освіти України: перспективи і шляхи впровадження ["Public health" specialty in higher education institutions of Ukraine: prospects and ways of introduction]. Спортивна медицина. 2019;2:8-13.

12. Конституція України. Київ: Алерта, 2011. 96 с.

13. Купер К. Новая аэробика; пер. с англ. Москва: Физкультура и спорт; 1979.124 с.

14. Курс лекций по общественному здоровью и здравоохранению. Часть. 1. Общественное здоровье. Москва: Медицина; 2001. 200 с.

mvd21@ukr.net зможуть переконливо донести до населення нашої країни, що фрізичний розвиток людини - це найважливіший показник його здоров'я. Тому підвищення мотивації до занять фрізичною культурою осіб різного віку, соціальних і професійних груп, як одного з найважливіших профрілактичних заходів, спрямованих на зміцнення здоров'я нації основна мета підготовки фрахівців зі спеціальності 229 Громадське здоров'я у Національному університеті фрізичного виховання і спорту України.

15. Лисицын ЮП, Комаров СМ. Факторы риска / Руководство по социальной гигиене и организации здравоохранения; под ред. Ю.П. Лисицына. Москва: Медицина; 1987. Т. 1. С. 148-200.

16. Медик ВА, Юрьев ВК. Общественное здоровье и здравоохранение [Public health and healthcare service]: учебник. Москва: Профрессионал; 2009. 432 c.

17. Міжгалузева комплексна програма “Здоров'я нації” на 20022011 роки. Київ: ОВ 2002. 88 с.

18. Могендович МР. Рефрлекторное взаимодействие локомоторной и висцеральных систем. Ленинград: Медгиз; 1957. 430 с.

19. Москаленко ВФ. Здоровье и здравоохранение: ключевые императивы [Health and healthcare service: key imperatives]. Киев: ВД "Авіцена", 2011. 256 c.

20. Москаленко ВФ, Грузєва ТС, Гульчій ОП. Теоретичні основи і розвиток науки та навчальної дисципліни “Громадське здоров'я". Громадське здоров'я: підручник для студентів вищих мед. закладів / Вінниця: Нова книга; 2013; Вип. 3. С. 18-43.

21. Муравов ИВ. Оздоровительные эфффекты ффизической культуры и сnорma [Health related effects of physical culture and sport] Київ: Здоров'я, 1989. 272 с.

22. Про схвалення Концепції розвитку системи громадського здоров'я від 30 листопада 2016 р. № 1002-р. Київ. https//zakon.rada.gov.ua/ show/1002-2016-\%D1\%80\#n8

23. Спортивна медицина; за ред. д. мед. н. Л.Я.-Г. Шахліної / Л.-Я.Г. Шахліна, БГ. Коган, ТО. Терещенко та ін. Київ: Олімпійська література; 2018. С. 111-142.

24. Футорний СМ. Формування поняття “Здоровий спосіб життя" у процесі фізичного виховання студентів ["Healthy way of life" in the process of student physical education]. Спортивна медицина. 2011; 1-2: 85-91.

25. Футорный СМ. Здоровьесберегающие технологии в процессе физического воспитания студенческой молодежи [Health maintaining technologies in the process of student youth physical education]: Монография. Киев: Саммит-книга, 2014. 296 с.

26. https://tsn.ua/ukraina/za-30-rokiv-naselennya-ukrayini-skorotilsya-na 20-0on-1364835.html

27. Passmore R, 1979. Цит. по Войтенко ВП. Здоровье человека. Введение в социологию. Київ: Здоров'я, 1991. С. 27.

28. Wolanski N. Zdrawie - szodowiskowe uwarunkowania i pozytywne mierniki. Zdrow. Publ. 1983; 94, 5:259-265.

Надійшла 25.02.2020 